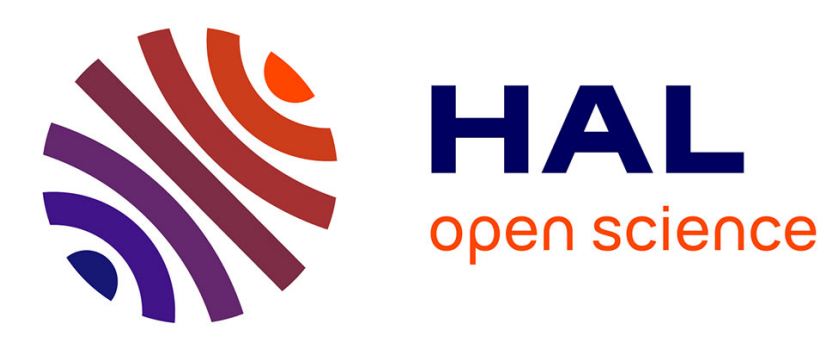

\title{
Rhetoric as a Means for Sustainable Development Policy \\ Gaël Plumecocq
}

\section{To cite this version:}

Gaël Plumecocq. Rhetoric as a Means for Sustainable Development Policy. Environmental Values, 2014, 23 (5), pp.529-549. hal-00994992

\section{HAL Id: hal-00994992 \\ https://hal.science/hal-00994992}

Submitted on 1 Dec 2014

HAL is a multi-disciplinary open access archive for the deposit and dissemination of scientific research documents, whether they are published or not. The documents may come from teaching and research institutions in France or abroad, or from public or private research centers.
L'archive ouverte pluridisciplinaire HAL, est destinée au dépôt et à la diffusion de documents scientifiques de niveau recherche, publiés ou non, émanant des établissements d'enseignement et de recherche français ou étrangers, des laboratoires publics ou privés. 


\title{
Rhetoric as a Means for
}

\section{Sustainable Development Policy ${ }^{1}$}

\author{
GAEL PLUMECOCQ \\ INRA - UMR AGIR \\ Chemin de Borde-Rouge - Auzeville \\ CS 52627 \\ 31326 Castanet-Tolosan \\ France
}

\begin{abstract}
This paper examines the hypothesis that all public policies are based, at least in part, on rhetorical strategies. By analysing public policies implemented in the context of sustainable development, this article emphasises the need for and the challenges of providing legitimate foundations for the rhetorical means used to encourage change; it is these foundations that determine a given policy's effectiveness. To do so, historical analyses are used, as well as socio-economic perspectives examined through textual analysis. The text concludes by showing the importance of a common framework for action based on shared values at the regional level for legitimising the political use of rhetoric to change behaviours and attitudes.
\end{abstract}

Key Words: public policies, rhetoric, needs, legitimacy, multidisciplinary approaches

\footnotetext{
${ }^{1}$ Translated from the French by Cynthia J. Johnson.
} 
Economic policies are intended to shape individuals' behaviour so that they act more in accordance with the common good. The assumption that rationality underlies the behaviours that need to be changed is therefore of fundamental importance. From the 'standard' economic perspective (Favereau, 1989), the rationality underlying behaviour is optimising, in other words, that individuals always seek to maximize the satisfaction of their interests. This assumption justifies representing individual interactions within a market framework (Arrow, 1974). However, in environmental management, this is a fictive market, in the sense that environmental goods do not have the same characteristics as manufactured goods (Polanyi, 1944). However, most economic analyses dealing with environmental policies only deal with the traditional tools of economic policies (Bürgenmeier, 2008) such as incentive tools (e.g. taxes or subsidies) or regulation. In doing so, economic analyses neglect other fundamental aspects of human functioning. For instance, emotions influence moral judgements that underlie political choices (Namkoong, et al., 2012) and shape the ways people practice citizenship - for example in partisanship or reflective deliberation (MacKuen, et al., 2010). Furthermore, the environment plays an important role in human emotional wellbeing (Rolston III, 1979).

Given the emotional dimension of choices and their role in shaping moral values, the usual tools of economic policies are far from neutral. When implementing them, various mechanisms are at work that go beyond the simple regulation of behaviour and individual interests. I would then argue that these tools follow an ideological agenda, that of neoliberalism (Dixon, 1998, Söderbaum, 1999) ${ }^{2}$. Therefore, relying on a discursive conception of rationality (to be rational is also to be able to provide socially acceptable justifications for one's actions, which could include emotional drivers), this paper considers 
other public policy means that are not exclusively economic, in particular those that employ rhetoric to encourage change. These rhetorical dimensions will be examined using a multidisciplinary method of analysis integrating both a genealogy of key historical events and textual analysis of socio-economic data.

The purpose of this paper is thus (i) to show that public policies are based as much (if not more) on rhetorical terms as on the usual tools of political economy; (ii) to emphasise the need to think about public policy in terms of the legitimacy of these rhetorical tools; and (iii) to base a policy analysis on an appropriate method. Such a method would necessarily be multidisciplinary, and not only because the environment is at stake here. Focusing on the processes by which individual behaviours are influenced also requires better understanding the complex sets of motives that individuals have in acting the ways they do, and not simply explaining them. As emphasis is put on rhetorical means, we have to account not only for the processes of persuasion that takes place in concrete situations, but also on the broader influences on collective representations (Searle, 1969). Shared values are important because they are the main basis for individuals to judge whether public actions are legitimate enough to be accepted (Section 1). As a result, we have to adopt a method enabling us to understand (i) the ways social values are progressively shared in relationship to the environmental history of the region studied, and (ii) the ways public policies depend on these values in order to promote sustainable development (Section 2). The analyses (Section 3) suggest the existence of three fundamental political dimensions: the use of rhetoric as a form of public action; the privileging of values that are shared throughout the territory; and reliance on a more or less fixed regional framing. Section 4 concludes with possibilities for profoundly changing the behaviour of various types of actors regarding sustainable development.

\footnotetext{
${ }^{2}$ From this point of view, monetising environmental goods so that they are better taken into account in policy decisions is potentially dangerous because the concept of monetary valuation allows for possible excesses, such as putting those goods on the market to be bought and sold (Spash, 2008).
} 


\section{Economic Policy and Sustainable Development at the Local Level}

From an economic perspective, policies are required in cases where (i) the free reign of individual interests is contrary to public interest and (ii) the promotion of the common good appears justified. In this conception of public policy, the teleological incoherence of individual interests potentially couples with the incoherence between collective interests and the sum of individual interests (Arrow, 1951). But individuals do not only have preferences; they also have needs, which should be given priority by public policies.

\subsection{A Needs-Based Conception of Economic Public Policy}

The framework of economic rationality - which I would qualify as means-oriented, is particularly suited to analysing economic choices. The strength of such kinds of analysis lies mainly in the epistemological position of value neutrality: homines economici are free to choose the options that maximise their interests (even if it affects their own well-being) according to their preferences, but regardless of moral considerations. In matters of sustainability, and more precisely of public policies of sustainable development, it is argued in this paper that individual preferences are not an entirely relevant analytical category: first, sustainability has moral implications incompatible with the behaviour of homo-economicus, in particular in regards to social justice (Vatn, 2005); second, preferences are incommensurables (Arrow, 1951) and therefore public policies are not competent to address them; and third, individuals may be unable to properly mobilize resources (that may be provided by governments), because they have limited cognitive capacities or information, or because they are much more driven by their emotions than their economic rationality.

Needs, on the other hand, are compatible with the moral requirements of sustainability (O’Neill, 2011). Needs can also provide the basis for a shared assessment, in particular because they can be reduced to fundamental living conditions (Jolibert, et al., 2011). MaxNeef and colleagues developed a framework making needs a useful analytical category for 
public policy (Cruz, 2011, Max-Neef, et al., 1989).This framework takes the opposite tack from the standard theory, by starting from the assumption that there are a limited number of fundamental needs. Each of these needs further breaks down into four existential criteria that are required for satisfying these needs, which policy choices can focus on. (Examples from interviews are presented to illuminate the ways public policies refer to the four existential categories in addressing the need of populations.)

- "Being", which defines the qualities specific to individuals ("they [colleagues outside the sustainable development department of the local government] are not used to bringing sustainability into their projects").

- "Having", which specifies things that allow one to meet material needs ("we [as policymakers] can keep providing High Environmental Quality infrastructures, but if they are not used, what good will it do?").

- Ways of "doing", which characterizes the uses of things for each of the needs ("in this region, we have $80 \%$ of the population living 5 minutes away from a highway and 5 minutes away from a train station. Yet, everybody takes their car!").

- And ways of "interacting", which refers to the procedures or the collective, spatialtemporal frameworks needed to satisfy those needs ("we [as civil servants in charge of sustainable development] must work with other departments [of the local government], but if nothing has been prepared at the political level we will not be able to move forward in our policy of sustainable development").

The entire group of basic needs can be broken down according to each existential criterion, which gives us a matrix of factors for satisfying basic needs (see the Appendix). It draws attention not only to "having" and "doing", but also to "being" and to "interacting" which enables us to highlight moral considerations and the social justice requirement of sustainability. 


\subsection{How Can Sustainable Development be Legitimised in Decision-Making?}

Nevertheless, the question remains: how to ensure that individual behaviour conforms to the will of public authorities (i.e., for using more sustainable infrastructure or limiting individual interests when they contradict the common good)? With Max-Neef's framework all the elements that contribute to the satisfaction of individual needs will be considered: "being", "having", "doing" and "interacting". As a result, the vision of public policy changes in two different ways:

- Firstly, the usual infrastructure policies are reclassified in regards to the procedures or collective spatial-temporal frameworks specific to satisfying individual needs (the “interacting"). In this regard, infrastructures provide "meaning to an unfolding strip of events" (Gamson and Modigliani, 1987: 144), provided they are supported by rules, norms or conventions.

- Secondly, the standard tools of economic policies that seek to change the ways of "doing" (regulatory and incentive tools) are relatively inefficient, as they consist in using public resources (notably in the form of subsidies and costs related to implementing control and sanction mechanisms) until the habits and routines, which define the way individuals use their own resources in meeting their needs, change.

In all cases, the ultimate goal of public policy is to influence the behaviour of individuals. In other words, it involves acting on individuals' ways of "doing”. This can happen either through the usual policies of supplying infrastructure (acting on "having" or "interacting"), or through tools seeking to modify ways of "being" over the more or less long term. The ways of "being" are particularly relevant when it comes to environmental political concerns, reshaping new conceptions of citizenship (Dobson, 2003). One of the fastest and most effective ways to effect "being" is through rhetoric. In this regard, policies can be compared to advertisements that convey a system of signs aiming at changing behaviours (Barthes, 1964). Moreover, as 
Austin (1962) and later Searle (1969) emphasised, not all the meaning of language passes through the semantic value of the words. We also have to account for the acts of language and acknowledge that rhetoric is not only displayed through written or oral language - that is rhetoric is not only bound by formal constraints to logically structure argumentation ${ }^{3}$. Rhetoric is also conveyed through the acts of language, which include the identity of the speaker (or agent), the tone, the gestures, and more broadly, the context of persuasion.

Consequently, the question that underlies public policies is not so much how to change individuals' behaviour, but how to assess the degree of legitimacy of these rhetorical strategies. As Perelman (1977) suggests, rhetoric is not only a cynical method of manipulation, a violent manifestation of power relationships, or an expression of bad faith. . Rhetoric can be legitimate when supported by shared values. Following the work of Boltanski and Thévenot (1991), there are several fundamental elements that guarantee the legitimacy of a decision or choice. First, a legitimate decision is a decision that fulfils a principle whose validity is conventionally accepted with regard to universal values (for example, fairness, efficiency, aesthetics or material wealth). In this sense, the decision appears to be right. Next, the legitimacy of a decision is evaluated in terms of the sum of material dispositions, institutions, objects, and people that make up the framing of the particular context in which the decision is considered. In this second sense, a legitimate decision must appear to be adapted to the situation. Rationality then appears as a capacity of judgment regarding the legitimacy of political rhetoric and decisions.

\section{A Multidisciplinary Approach}

This approach to decision-making and rhetoric requires a methodology that enables us to understand both the formation of values legitimising the use of rhetoric in public policy, as

\footnotetext{
${ }^{3}$ Actually, this has long been known, since Aristotle (2012) brought together the concepts of logos (the rational and logically structured discourse), pathos (the ways in which the speaker arouses empathy by playing on
} 
well as the various aspects of rhetoric brought into play in those public policies. Such a method is necessarily interdisciplinary (Norgaard, 1989): an historical approach makes it clear how latent values are forged and progressively shared by populations through an intermingling of social and economic relations (Hards, 2009), while a socioeconomic approach (interviews) enables us to assess how these values are politically activated in order to justify sustainable development policies. These two parts of the method are complementary. Shared values are tacit by nature. The historical method enables them to be made explicit and to be characterized, whereas interviews reveal how these values were politically activated in a rhetorical way and may be legitimated. Moreover, sustainability is not an objective in itself. It is a horizon: always in sight, but never reached (Emelianoff, 2002). Political achievements must then be compared over time, rather than in space. In this paper, I will (i) provide an historical background of the genealogy of key events, (ii) present the socioeconomic data collected (interviews), and the method of textual analysis used to process them (Alceste software), which (iii) enables us to tease out the semantic saliences of political actions.

\subsection{How Values Are Constructed: Historical Perspectives}

Genealogy is a method used both by history and biology. Applied to evolutionary psychology, it suggests that from a certain point of view, human beings behave like an ecological system, which provides useful insight about the production of shared values, in particular concerning sustainable development (Jackson, 2003). The history of the regional development of the area studied here - the Nord Pas-de-Calais region (northern France) - highlights the ways in which values of solidarity, productiveness, determination, bravery, hard work, etc., were progressively and collectively forged. These values provide a moral foundation for the legitimation of sustainable development policies currently in place. 
The region took off with the discovery and then the mining of coal in the $1850 \mathrm{~s}$. Hard hit by the First World War (140 of 212 shafts were destroyed), the industry restructured during the interwar period and in 1940, 60\% of France's domestic coal production was provided by the Nord Pas-de-Calais region. World War II marked a turning point in the mining history of the region and its development. Beyond the scale of destruction that affected the region, the post-war period was marked by the nationalization of mining companies in order to contribute to the national reconstruction effort. The wealth that was thus recovered by the region (mainly in the form of land holdings or real estate investments) was then redeployed throughout the entire country. Regional coal production was also streamlined during this period: shafts were gradually closed while production levels remained constant. This productivist pressure culminated in the early 1970 s when operations were almost stopped. This dramatic history over nearly 150 years profoundly marked the collective imagination of the region as well as its landscape.

This history shaped the territorial identity of the region (Plumecocq, 2012): in the industrial development period, the population identified themselves as hard-working, volunteering, and united people. These values have been transmitted through two kinds of channels. On the one hand, the mining companies' construction of living areas (mining towns, corons) shaped a regime of familiarity (Boltanski and Thévenot, 1991) specific to industrial paternalism of the nineteenth century. This anchoring of people in community spaces affected not only the miners themselves, but also their families who played the role of both receptacle and then vehicle for the transmission of this history and its values. On the other hand, this history developed in close relationship with the inhabitants' attachment to the region. This attachment stems from two ideas shared by the people (but potentially contradictory!):

- First, the idea that the resource responsible for the region's growth is a natural resource. This, in turn, is the source of the wealth that has been maintained throughout the 
area (transport networks, mining infrastructure, built heritage, etc.), and which is particularly evident in the architectural patrimony of the region. This heritage thus serves as a link between a past golden age and community values that are still in force today.

- Second, the idea that this history resulted in a disastrous socio-economic situation (in some cases, certain cities have lost almost a fifth of their population since the end of the industrial era in 1970), but also in ecological terms (half of the polluted soils in France are located in the region, 10,000 hectares of the region are brownfields, the groundwater is polluted, and so on (Scarwell, et al., 2008)). The regional population also positions itself in relation to this very negative assessment, and this enables them to share and inherit values such as willingness to work, reciprocity, and solidarity.

This history (including recent history) probably explains why environmental awareness developed earlier in the Nord Pas-de-Calais than in other French regions (Emelianoff, 2005) and why local authorities began a turn towards sustainable development, building on the values related to work and solidarity, including at the territorial level (Zuindeau, 2007), values that had been forged during the course of the region's history.

\subsection{Methods and Data: a Socio-Economic Analysis}

Because of its history, the Nord Pas-de-Calais constitutes an informative case study. At the forefront of sustainable development policies in France, it has two advantages of a pioneering region: 1) sufficient empirical data exists, both in quantity (many local authorities in the region have established a sustainable development programme) and in quality (the range of the types of local authorities that have implemented such plans is sufficiently varied); and 2) since certain local governments began their sustainable activities about fifteen years before the interviews were conducted, the implementation of sustainable policies can be traced over a sufficient period of time. Moreover, with their collective memory of over one hundred years of the worst aspects of industrial development, the region's inhabitants were eager for its 
opposite, which thus served as a sort of latent, cognitive resource and called for a more sustainable regional development.

To understand the ways in which latent values are reactivated through public strategies for sustainable development, several institutions representative of public interest and of political will were selected: local authorities (the regional government and that of the two départements, the Public Institution for Intermunicipal Cooperation ${ }^{4}$, municipalities, and institutions that group together rural villages (pays)), the local offices of national government, and local community organisations (public interest groups). A total of twenty-one institutions, whose decisions appear as a legitimate expression of public will, were investigated. Thus, the data collected are not discourses directed at citizens or aimed at convincing them that they act for the greater good. Therefore, no particular attention has been paid to the institutions through which discourses are mediated (Rydin, 1999). Interviews are solicited explanations of what was done, intended, abandoned, or achieved, with what difficulties or barriers, using what methods, in terms of sustainable development policies. Here, textual analyses are not meant to criticise the ways "sustainable development" is used in political speeches (e.g. see Alexander, 2008, in particular chapter 5 that analyses the textual usage in "sustainable development" by Shell). Given this informative status of interviews, textual analysis is used to reveal and organise evidence.

Efforts were made to obtain a representative coverage of the region, particularly regarding the distribution of the various towns, the EPCI, and the pays within each department. The same number of EPCI and pays were visited in each département (two and one, respectively). As for the towns, three were located in the Pas-de-Calais and four in the Nord département. This asymmetry is fairly representative of the actual steps taken at the regional scale. For example, two of the three towns in the Pas-de-Calais have not adopted sustainable

\footnotetext{
${ }^{4}$ Etablissements Publics de Coopération Intercommunale or EPCI
} 
development approaches as such, but have developed related programs (such as those for greater solidarity and social equity in the economy or urban redevelopment schemes).

The key players identified within these local institutions were surveyed. As the Alceste method of textual analysis builds classes of co-occurrent words, it would later be used to reconstruct the structure of the interviews. Relatively free-form interviews were then conducted and transcribed to be statistically processed by Alceste. The questions concerned the implementation of sustainable development policies (notably emblematic or remarkable successes and / or failures), the difficulties encountered and the meaning of the concept of sustainable development. In order to obtain the most complete vision possible, interviews with the staff ( 21 total) were complemented, when possible, with interviews of the elected officials in charge of these issues ( 5 in total). In two municipalities, the person in charge of sustainable development was also the mayor's chief of staff. These twenty-eight interviews were then transcribed in full into a textual corpus that was analysed using the software Alceste.

\subsection{Multi-dimensional Public Policies}

The method used in this paper broadly relates to discourse analysis, in the sense that it provides quantitative and qualitative evaluation of both the contents and the context of oral or written discourses (Harris and Dubois-Charlier, 1969, Pêcheux, 1969). The main interest of textual analysis methods is that they ensure that results are reproducible. These methods also reveal in a very clear manner the different aspects of an interview or a text. The method used - the Alceste method of data processing - results in a classification of the interviews into "lexical worlds" (Reinert, 1993), that is to say, in classes composed of words considered to be semantically close. The originality of this method is based on this concept of proximity. While the majority of alternative approaches group together terms or text segments based on rules (i.e., grammatical) or according to meaning defined a priori (such as by dictionaries), 
Alceste starts from the assumption that the epistemic value of a word comes from the context in which it is used - the context of action that is translated into a context of words. Moreover, the meaning of the text as a whole comes from the association of co-occurent words among themselves (significance is measured by the chi-square test). From this point of view, there is no interest in words alone taken out of context. Thus, the results and the classification provided by Alceste require us to interpret the totality of the analysed corpus. The interpretation of the structure of the discourse will enable to better understand the intent even unconsciously, of the speaker. In this case, no distinction (i.e., no coding) has been made in regards to the identity of the people interviewed, which appear on the whole as an abstract figure: the "decision-maker". Analysing the classification of the discourse will then enable us to highlight the key dimensions the decision-maker selects when implementing sustainable development policies.

Technically-speaking, Alceste begins by establishing successive descending hierarchical classifications. The text formed by the ensemble of interviews is immediately considered as a unit of meaning, within which semantic nuances "hide". The software then proceeds by arbitrarily dividing the corpus into elementary context units (ECU), that is to say, portions of text that are more or less equivalent in size (per number of words). Next, it makes associations among the ECUs by identifying the words that are the most significantly associated with each other within a given ECU (significance is evaluated using a chi-square test) ${ }^{5}$. When the software has tested every possible way of associating the different ECUs, it selects the most significant classification. In a third step, Alceste then eliminates the arbitrary effect resulting from calculating the size of the ECUs, by performing a second classification based on a

\footnotetext{
${ }^{5}$ The value of chi-square does not have the usual meaning of measuring the possibility of error or of applying a law of probability to a given sample. Here, it determines the probability that a word has been attributed to a class randomly. The association of a word to a class begins to be significant from a chi-square value equal to 3.84 , that is to say when there is a $0.1 \%$ chance that the word has been associated to a class fortuitously.
} 
different ECU size. Finally, the software selects the classification that has been established from the intersection of these two previous 'simple' classifications.

The analysis carried out on the entire corpus led to the classification presented in Figure 1. Four constituent discursive dimensions of public discourse on sustainable development are distinguished. Linking these different dimensions of sustainable policies at the local level will show how and through what channels (an aspect often neglected in the literature) and with what legitimacy public policies have been implemented.

\section{Figure 1 -The Four Discursive Dimensions of Local Sustainable Development}

\section{Policies}

When trying to encourage people to act in accordance with collective interests by referring to sustainable development, local public policy makers respond to the history of the region's economic development and its aftermath. By putting into perspective the practical difficulties of coordinating public decisions throughout the region (semantic class 3 ) - an objective often singled out among sustainable development issues, particularly at the local level - local policies emphasize the need to respond in a more sustainable way to people's needs (semantic class 2). In order to do so, they called upon regional history and shared values, which is reflected in the rhetorical and exemplary-model vocabulary that they employed (semantic class 1). As a result, the region became specialized in the mastery of this cognitive resource (in the technical sense defined above). This of course raises the problem of internal reorganization in local governments (class 4), which is very important in some respects, but is beyond the scope of the present article. 


\section{Rhetoric, Values, and Legitimacy}

These four discursive dimensions at work in sustainable development policies, and as reflected objectively by the textual analysis tool, enable us to reconstruct what is at stake in the political mobilisation of this "referential framework" (Muller, 2005). Interpreting these results in light of the historical evidence shows the ways in which this reference to sustainable development is used to (re)-legitimise government action. This legitimation occurs by calling upon values connected with the cultural identity of the region when undertaking public actions.

\subsection{Rhetoric and Exemplary Models}

At first glance, semantic class 1 may seem rather complicated to interpret. Indeed, classifying words by grammatical family shows that common nouns are relatively insignificant in this class $\left(\chi^{2}=-134\right)$, which would indicate a smaller epistemic dimension than the other three. It is important, however, to note that verbs $\left(\chi^{2}=125\right)$ and person markers $\left(\chi^{2}=60\right)$ represent the most significant parts of discourse in this class. The vocabulary employed here is actionoriented, not only through the construction of a system of beliefs about what people $d o^{6}$ or say, but also with the implementation of sustainable development projects that are considered innovative, particularly through the local Agenda 21 plans (advances, change, do).

The vocabulary in this group, which is semantically rather poor, is based on three rhetorical elements: communicative (talk, say, ask), seeking out and sharing exemplary models (go, come, give, take, see, use, look) and future-oriented (move forward, advance, know, change, come next, improve). These three elements are combined for a persuasive and rhetorical purpose (believe), not only to encourage people to do the right thing, but to convince them of the validity and the interest in adopting sustainable values and behaviours.

\footnotetext{
${ }^{6}$ Hereafter, words in italics will refer to the words analysed and classified by Alceste, as translated into English by the translator. The original interviews and textual analysis were conducted in French.
} 
Thus, this method reveals for the first time justifications for sustainability that are based on building consensual “interacting" - in Max-Neef's sense, rather than on conflict.

The relationship of public actors working on sustainable development with other actors of local government occurs in the mode of "volitional pragmatism" - in the sense of thought in action (Bromley, 2008), by comparing actions, notably by highlighting virtuous examples. This conception of sustainability is opposed to what Redclift (1993) calls the Modernist view of sustainable development, in which the social criticisms directed against unlimited economic growth and scientific dominance on knowledge production still leaves room for technological optimism. Here, particular emphasis is placed on actual sustainable development processes and projects, as well as on cultural factors. Depending on the type of actors involved, this may involve either sharing a specific experience in such a way that other actors can benefit from effective programmes already in place, or instructing and educating the relevant staff and / or citizens about the overall approach to sustainable development (pedagogical, teacher) (Dobson, 2003). Thus, in the words of Dobson (2007), the issue is not only changing individuals' behaviour, but also more deeply, their attitudes about what is at stake with sustainability, being understood of course that a change of attitude will likely change behaviour, while the opposite is not necessarily true. In this rhetorical dimension, sustainable development is then meant to effect the categories of "beings" required to address needs.

\subsection{Appealing to Regional Values in Policy}

Semantic class 2 refers to those aspects of public policy involved in the issue of sustainable development. This group reveals the elements that reactivate the latent regional values forged through history. The vocabulary of this class refers to the various sectors of local policies, especially social policies: housing (inhabit, build, housing, neighbourhood), employment, public transportation (train, mobility), urban planning, green space management and so forth 
directly related to people's needs. Note also the use of terms specific to environmental issues (energy, water, resources, waste). However, sustainable development is not juxtaposed to traditional policies and the principle of integration is clearly at the heart of this semantic group (social, economic and environmental). This group also contains terms referring to the ways in which this principle is institutionally understood: point, section, theme, dimension. Issues involving the assessment of both the environmental and socio-economic impact of policies put in place support the view that the principle of integration is at the heart of this semantic class. Finally, this group also reveals a vision of public policy in terms of achieving balance, which is identified as an issue or a problem that is not easy to resolve.

It is within this discursive dimension that the values and the cultural identity specific to the Nord Pas-de-Calais region have been reactivated. This occurred through a policy of promoting the industrial and mining heritage in relation to the concept of sustainable development, a policy implemented by local governments in a homogenous manner throughout the region. Three particularly instructive policy areas can be identified:

- The cultural policies of local authorities of the region are based on rehabilitating the industrial infrastructure: former mining sites have been turned into museums or leisure parks, and some slag heaps (geographical features formed by the accumulation of mining residue) have been secured and opened to walkers.

- Housing policies also rely on the rehabilitation of mining settlements (corons) to reuse existing buildings and to promote this heritage in a more sustainable ways: the social housing characteristic is kept, and the buildings have been equipped with a rainwater recovery system, energy efficient systems, and so forth.

- The policy Trame Verte et Bleue is an important part of the region's environmental policy, and seeks to stitch together various parts of the region into a green 
infrastructure in accordance with the characteristics of its natural environment. This biological corridor project reuses the cavaliers, the railroads that linked together the various mining sites.

A common principle guides all of these policies: to reuse the infrastructure produced in the era of industrialization by promoting these assets in terms of sustainable development. Reusing former industrial infrastructure for cultural, housing and environmental preservation purposes is thus ultimately conceived of as part of one historical continuity. Highlighting the patrimonial heritage that embodies the values of the region's cultural identity helps to legitimise sustainable development policies, by focusing both on the "being" dimension of the population, though the production of collective "having".

\subsection{Framing Public Action and the Legitimacy of Sustainable Development in}

\section{Regional Terms}

The semantic class 3 allows us to grasp how sustainable development policies rely on framing (in the sense of Kahneman and Tversky (1981)), which tends to objectify the sustainable development approach. This framing is the regional territory (local, urban, rural, Nord Pasde-Calais), understood as a coherent spatial unit of public governance, as well as an institutional space. Through this semantic class, the region is seen as a space of complex coordination (with various levels of authority and overlapping institutions), in which different levels of regulation are entangled (Gilly and Wallet, 2005). Sustainable development policies are thus seen as an opportunity to give meaning and coherence to the territory, by moving beyond the administrative structures that created the framework for the industrial development of the past century. Governmental fragmentation is then seen as a challenge that must be overcome by inventing, or reinventing, means of cooperation (with, together, share, cooperate). "Interacting" means are not only interpersonal, but also inter-territorial. Several types of resources are mobilized for this purpose: legal means (juridical/judicial), via the 
establishment of a charter or regional contract; institutional means, created to promote direct cooperation between local authorities (pays, community, intermunicipality); relational means (networks, partner) mainly fostered by the creation of institutions (agency) or specifically dedicated to bringing together various sustainable development initiatives; and finally, one common to all of the other means just mentioned: establishing projects that develop areas of "interacting", such as the regional climate plan. The implementation of all of these means of cooperation is justified by the fact that public decisions on sustainable development need to be made in regard to the territory. The values of fairness and solidarity invoked in this justification of public policies is thus all the more acceptable because it is rooted in the culture of the people (Zuindeau, 2007).

Local authorities also reflect on the relationship between the goals they wish to achieve and the resources, primarily financial (budget) but also regulatory and institutional, that they possess for carrying out those goals. From this perspective, the concept of sustainable development is strategically used in such a way as to situate public action within an integrated regional framework, thus changing the context in which local governments interact. In so doing, and by playing on the category of "interaction" as described by Max-Neef, et al. (1989), policy makers are likely to create conditions in which their actions appear legitimate, especially since they base their actions on values that are already present in the regional collective unconscious. The context in which public actions take place is thus the factor that links social interactions and values together in a sort of co-evolutionary mechanism (Hards, 2009). Actions thus come into line with values, this time configured not only in terms of the territory, but also in terms of sustainable development.

Thus, when public actors of sustainable development policies seek to justify public policies, three basic dimensions can be observed: first, using the rhetoric of policy administration that is intended to change actors' ways of "being" (public or private) by 
instilling a civic dimension with respect to sustainability (Dobson, 2003); second, employing discourse that depicts sustainable policy as a heritage and a patrimony, in which shared regional values are reactivated; and finally, situating sustainable development within a regional context that provides an objective framework for considering issues both in regional and sustainable terms. These three dimensions form the underlying basis of local policies for sustainable development. From the perspective of political practices, this requires the mobilization, sometimes explicitly, of values that justify this political commitment to sustainability.

\section{Conclusion: The Possibility of a Collective Change in Attitude}

The frame of reference of sustainable development is not only mobilised in order to change the mode of development of the region. It is also done in order to deeply change people's behaviour, to influence decisions of other local authorities, and also to build support for these ideas among the civil servants working within local governments. It remains nevertheless true, as Dobson (2007) notes, that neither self-interest nor the force of habit are powerful enough forces to change attitudes towards sustainable development. Such a change requires a deeper adherence to these values. In the case studied here, this adherence to values is fostered by relying on the framing that consists of a built heritage and a regionalised cultural history, which support these shared values. The extent of the commitment to sustainable development is reflected in the rhetorical dimension of discourse, which reveals one of the most fundamental modes of public policy and which is here legitimised: it is no longer a question of simply "producing" sustainable development, but also of convincing people to take responsibility for making it a reality (Ostrom, 1996).

In this regard, sustainable development policies are understood in terms of two levels of prescription. The first is part of normal economic or regulatory incentives, which occurs by modifying traditional public policy procedures, for example: introducing clauses guaranteeing 
that sustainability issues will be included in government procurement contracts or in the outsourcing of public services; requiring certain environmental conditions for giving subsidies to associations, for funding or grants for businesses or other local authorities, or supporting the development of sustainable industries to help them meet public demand; creating technical norms and standards; funding for HQE (High Quality Environmental standard, or green building) construction and certification, etc. With these prescriptive methods, the goal is to spread the adoption of sustainable behaviour by changing work habits or the way in which actors function, to create the supply conditions for sustainable products within the region by developing new know-how (or rediscovering others that were in the process of disappearing), and to help finance the consumption of sustainable goods that are often more expensive than standard products. Regional governance is thus based on the standard institutional mechanisms of economic policies, without seeking to fundamentally change citizens' value systems, nor to change their attitude towards sustainable development or their ways of "being”". Nonetheless, these policies do have some impact. (Dobson and Bell, 2006).

At the second level, complementary to the first, sustainability moves beyond the market framework and policy impact takes on a rhetorical value (no longer merely an incentive one). This involves accepting that the recipient of public services also has a role to play in the production of those services (Ostrom, 1996). In other words, to be effective, any public policy, and even more so sustainable development policies, must necessarily not only have the people's support, but also make them participate in the successful implementation of that policy. In this sense, citizens are no longer merely seen as consumers, but also as being able to accept or reject arguments or examples given to convince them to adopt a more sustainable approach.

This division between rhetoric and incentives allows us to classify various stakeholders of the governance of sustainable development within the region. The relationships that these 
stakeholders have with local government authorities can also be seen though this division: incentive remains a mode of interaction that has largely been developed within an economic framework, particularly with the corporate world, but also with other local governments (or even with outsourcers of public services), associations or even individuals (who are termed service users). The rhetorical aspect, however, is more complex to analyse. According to Perelman, all rhetoric must first be understood as a relationship between a speaker and his or her audience, defined as "all of those whom which the speaker wants to influence by his [or her] argumentation" (Perelman, 1977: 32). He thus distinguishes between the universal audience, composed of all of those who can potentially hear the discourse, and the specific audience to whom the discourse is directed. This distinction enables us to identify two types of stakeholders in the rhetoric of sustainable development: the universal audience that corresponds to citizens, populations, civil society, even all human beings; and the particular audience that is made up of regional civil servants and elected officials, as the first group involved with the successful implementation of sustainability. The speaker's goals are different depending on the type of audience addressed: the inhabitants must be "convinced" of the merits of sustainable development; government personnel and elected representatives must be "persuaded" that this is a good policy and the right way of doing things, in order to commit themselves to "doing"?

\section{Figure 2 - Two Complementary Public Policy Processes}

This threefold distinction between economic incentives, persuasion and conviction, as well as the various actors targeted by these modes of public policy, are shown in Figure 2. One

\footnotetext{
${ }^{7}$ The difference between conviction and persuasion has long been the subject of intense debate. For Pascal (1670), for example, the conviction is based on reason, whereas persuasion is based on passion, while for Kant (1781), the former is objective, while the latter is subjective.
} 
major difference among them concerns the extent of public willingness to act directly on the actors' value systems. Incentives do not involve collective values and they produce, or at best, limit learning results to a "simple loop learning" (Argyris, 1993: 67): action strategiesconsequences - revision and adaptation of the strategic plan. The best that can be expected is a change in routine behaviours over a relatively long period of time.

In each of the other two modes, collective learning results in behavioural change on the condition that another form of adherence takes place at the level of values. In fact, collective learning can only occur through a re-examination of the "core values" that underpin action strategies. It is only once people adhere to the new value system, which requires a certain strength of conviction to do so as well as a framing within which sustainable development appears as legitimate, that these individuals will be able to appropriate sustainable issues and put them into practice (Argyris, 1993). In the case of Nord Pas-de-Calais, on one hand, the adoption of sustainable values by inhabitants and civil society can be seen through the possibility of a change in attitude related to a potential change in ways of "being", and on the other hand, with civil servants and elected officials, through a change in administrative culture (working across departments, participation, collaboration, global thinking, etc.) which occurs at the "interacting" level. The activation of latent shared values, then, enables processes of collective learning that legitimise sustainable development policies, improving their effectiveness.

\section{Acknowledgments}

This paper partly relies on an innovative method of textual data treatment. As interviews were carried out in French, I am particularly grateful to Cynthia Johnson who helped me make this paper as comprehensible as possible by capturing in the best way possible the meaningful essence of the words provided in the semantic classification. Thanks also go to the two 
referees for their helpful comments and advice, and to Katie McShane for her excellent editorial work on this paper.

\section{References}

Alexander, R.J. 2008. Framing discourses on the environment: a critical discourse approach. Routledge: New York.

Argyris, C. 1993. Knowledge for Action. A Guide to Overcoming Barriers to Organizational Change. Jossey-Bass Publishers: San Francisco.

Aristotle 2012. Rhetoric. The University of Adelaide (eBooks@Adelaide): Adelaide, Australia, Translated by W. Rhys Roberts, http://ebooks.adelaide.edu.au/a/aristotle/a8rh/index.html.

Arrow, K.J. 1951. Social Choice and Individual Values. Crawles Foundation for Reaserch: Yale University.

Arrow, K.J. 1974. 'Limited Knowledge and Economic Analysis'. American Economic Review 64: 153-166.

Austin, J.L. 1962. How to do things with words. Paperback: Harvard University Press: Cambridge.

Barthes, R. 1964. 'Rhétorique de l'image'. Communications 4: 40-51.

Boltanski, L. and L. Thévenot 1991. On Justifications: the Economies of Worth. Princeton University Press (Translation, 2006): Princeton and Oxford.

Bromley, D.W. 2008. 'Volitional Pragmatism'. Ecological Economics 68: 1-13.

Bürgenmeier, B. 2008. Politiques économiques du développement durable. de Boeck (Third edition): Bruxelles.

Cruz, I. 2011. 'Human needs frameworks and their contribution as analytical instruments in sustainable development policy-making', in Rauschmeyer, F., I. Omann and J. Frühmann (eds.), Sustainable Development. Capabilities, needs, and well-being, pp.104-120. London: Routledge.

Dixon, K. 1998. Les évangélistes du marché. Raisons d'Agir: Paris.

Dobson, A. 2003. Citizenship and the Environment. Oxford University Press: Oxford.

Dobson, A. 2007. 'Environmental citizenship: towards sustainable development'. Sustainable Development 15: 276-285.

Dobson, A. and D. Bell 2006. Environmental Citizenship. MIT Press: Cambridge, MA.

Emelianoff, C. 2002. 'Comment définir une ville durable ?', in Villes et développement durable. Des expériences à échanger, http://base.d-p-h.info/en/fiches/dph/fiche-dph8294.html.

Emelianoff, C. 2005. 'Les agendas 21 locaux : quels apports sous quelles latitudes ?'. Développement durable et territoire, http://developpementdurable.revues.org/532.

Favereau, O. 1989. 'Marchés internes, marchés externes'. Revue Économique 40: 273-328. 
Gamson, W.A. and A. Modigliani 1987. 'The changing culture of affirmative action', in Braungart, R.G. and M.M. Braungart Research in Political Sociology (Vol 3), pp.137-177. Greenwich, CT: JAI Press.

Gilly, J.-P. and F. Wallet 2005. 'Enchevetrement des espaces de regulation et gouvernance territoriale : Les processus d'innovation institutionnelle dans la politique des pays en France'. Revue d'Economie Régionale et Urbaine 2005/5: 699-722.

Hards, S. 2009. 'Social Practice and the Evolution of Personal Environmental Values'. Environmental Values 20: 23-42.

Harris, Z.S. and F. Dubois-Charlier 1969. 'L'analyse du discours'. Langages 4: 8-45.

Jackson, T. 2003. 'Sustainability and the 'struggle for existence': The critical role of metaphor in society's metabolism'. Environmental Values 12: 289-316.

Jolibert, C., M. Max-Neef, F. Rauschmayer and J. Paavola 2011. 'Should We Care About the Needs of Non-humans? Needs Assessment: A Tool for Environmental Conflict Resolution and Sustainable Organization of Living Beings'. Environmental Policy and Governance 21: $259-269$.

MacKuen, M., J. Wolak, L. Keele and G.E. Marcus 2010. 'Civic Engagements: Resolute Partisanship or Reflective Deliberation'. American Journal of Political Science 54: 440-458.

Max-Neef, M., A. Elizalde and M. Hopenhayn 1989. 'Human Scale Development An Option for the Future'. Development Dialogue. A Journal of International Development Cooperation 1: 7-80.

Muller, P. 2005. 'Esquisse d'une théorie du changement dans l'action publique. Structures, acteurs et cadres cognitifs'. Revue Française de Science Politique 55: 155-187.

Namkoong, K., T.K.F. Fung and D.A. Scheufele 2012. 'The Politics of Emotion: News Media Attention, Emotional Responses, and Participation During the 2004 US Presidential Election'. Mass Communication and Society 15: 25-45.

Norgaard, R.B. 1989. 'The case for methodological pluralism'. Ecological Economics 1: 37-57.

O'Neill, J. 2011. 'The overshadowing of needs', in Rauschmeyer, F., I. Omann and J. Frühmann (eds.), Sustainable Development. Capabilities, needs, and well-being, pp.25-42. London: Routledge.

Ostrom, E. 1996. 'Crossing the Great Divide: Coproduction, Synergy, and Development'. World Development 24: 1073-1087.

Pêcheux, M. 1969. Analyse automatique du discours. Dunod: Paris.

Perelman, C. 1977. L'empire rhétorique. Rhétorique et argumentation. Librairie philosophique J. Vrin (Édition, 2002): Paris.

Plumecocq, G. 2012. 'Ressources cognitives et développement territorial : une analyse textuelle appliquée aux politiques locales de développement durable'. Revue d'Economie Régionale et Urbaine 2012/5: 765-782.

Polanyi, K. 1944. The Great Transformation: The Political and Economic Origins of Our Time. Beacon press: Boston.

Redclift, M. 1993. 'Sustainable development: needs, values, rights'. Environmental Values 2: 3-20. 
Reinert, M. 1993. 'Les "mondes lexicaux" et leur "logique" à travers l'analyse statistique d'un corpus de récits de cauchemars'. Langage et Société 66: 5-39.

Rolston III, H. 1979. 'Nature and human emotions', in Miller Jr., F.D. and T.W. Attig (eds.), Bowling Green Studies in Applied Philosophy, Volume1 - Understanding Human Emotions, pp.89-96. Bowling Green, Ohio: The Applied Philosophy Program.

Rydin, Y. 1999. 'Can we talk ourselves into sustainability? The role of discourse in the environmental policy process'. Environmental Values 8: 467-484.

Scarwell, H.-J., C. Kergomard and R. Laganier (dir.) 2008. Environnement et gouvernance des territoires. Enjeux, expériences et perspectives en région Nord-Pas de Calais. Presses Universitaires du Septentrion: Villeneuve d'Ascq.

Searle, J. 1969. Speech acts: an essay in the philosophy of language. Cambridge University Press: Cambridge.

Söderbaum, P. 1999. 'Values, Ideology and Politics in Ecological Economics'. Ecological Economics 28: 161-170.

Spash, C.L. 2008. 'How much is that ecosystem in the window? The one with the bio-diverse trail'. Environmental Values 17: 259-284.

Vatn, A. 2005. Institutions and the Environment. Edward Elgar: Cheltenham, UK, and Northampton, USA.

Zuindeau, B. 2007. 'Territorial Equity and Sustainable Development'. Environmental Values 16: $253-268$. 
Figure 1 -The Four Discursive Dimensions of Local Sustainable Development

\section{Policies}

\begin{tabular}{|lr|}
\hline \multicolumn{2}{|c|}{ Class 1 } \\
\hline Form & Chi 2 \\
\hline thing & 140,2 \\
people & 115,0 \\
do & 113,9 \\
come & 82,3 \\
it & 60,3 \\
say & 58,9 \\
time & 50,2 \\
itself & 49,9 \\
not & 45,5 \\
see & 44,0 \\
succeed & 42,7 \\
have to & 41,3 \\
go & 39,1 \\
world & 39,0 \\
you & 35,7 \\
take & 33,9 \\
that & 33,2 \\
moment & 31,8 \\
\hline
\end{tabular}

\begin{tabular}{|lr|}
\hline \multicolumn{2}{|c|}{ Class 2 } \\
\hline Form & Chi 2 \\
\hline Social & 356,1 \\
Economy & 340,7 \\
sustainable & 252,0 \\
energy & 244,2 \\
water & 175,3 \\
resource & 126,1 \\
consummation & 122,5 \\
environmental & 119,9 \\
renew & 90,9 \\
employment & 86,4 \\
eco & 83,0 \\
management & 87,8 \\
bind & 74,8 \\
development & 73,3 \\
town-planning & 73,0 \\
question & 68,6 \\
transport & 66,0 \\
need & 61,2 \\
\hline
\end{tabular}

\begin{tabular}{|lr|}
\hline \multicolumn{2}{|c|}{ Class 3 } \\
\hline Form & Chi 2 \\
\hline State & 266,2 \\
Region & 251,8 \\
Put & 111,4 \\
agenda_21 & 110,1 \\
Regional & 108,1 \\
National & 99,9 \\
Contract & 99,3 \\
CERDD & 95,4 \\
Action & 93,5 \\
Committee & 91,6 \\
Strategy & 85,1 \\
Country & 74,3 \\
Project & 73,8 \\
Tool & 63,6 \\
Different & 63,4 \\
Territorial & 63,0 \\
Direction & 61,9 \\
Operation & 61,3 \\
\hline
\end{tabular}

\begin{tabular}{|lr|}
\hline \multicolumn{2}{|c|}{ Class 4} \\
\hline Form & Chi 2 \\
\hline community & 848,7 \\
urban & 340,3 \\
town & 294,7 \\
Vice-president & 257,5 \\
president & 227,9 \\
planning & 225,3 \\
delegation & 137,8 \\
city & 125,4 \\
in charge & 103,0 \\
director & 98,0 \\
mayor & 77,1 \\
responsible & 75,8 \\
Lille & 68,7 \\
territory & 67,0 \\
competent & 61,6 \\
direction & 59,5 \\
elected & 58,7 \\
mission & 46,2 \\
\hline
\end{tabular}


Figure 2 - Two Complementary Public Policy Processes

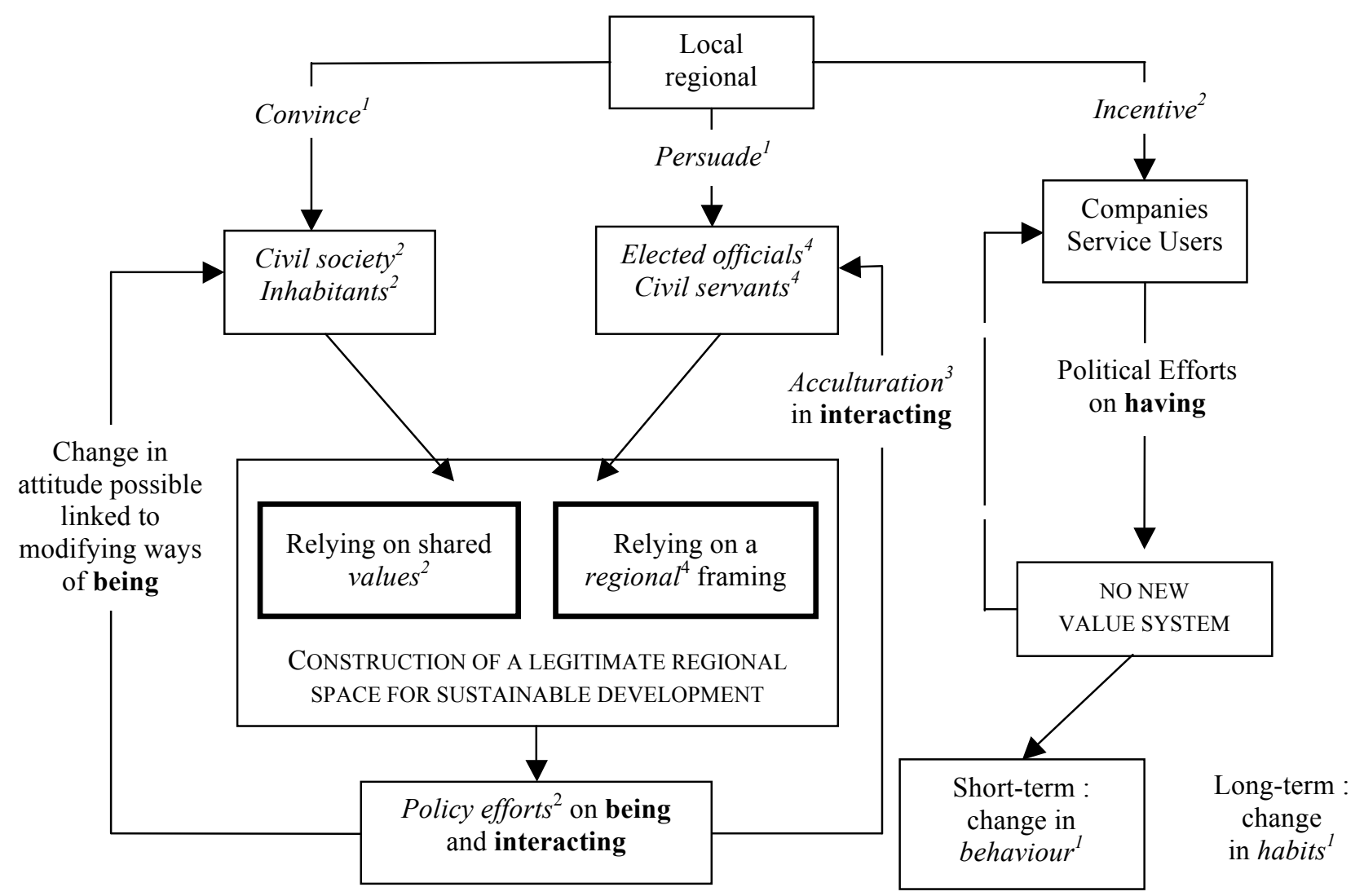

The Figure represents the processes of political decision making: incentive, persuasion, and conviction. Words highlighted in italics are those identified in the textual analysis (semantic classes appear in exponent). Max-Neef's four existential criteria are represented in bold. 